\title{
Foreword
}

\section{Yasuyuki Sawada}

Fiscal sustainability has not been a major policy concern in developing Asia. Reflecting conservative policies and speedy responses to fiscal slippages, budget deficits in the region have generally been small, and public debt has not climbed to the very high levels seen in many other parts of the world, in relation to gross domestic product. For the most part, Asian governments have displayed the same frugality that has characterized many of the region's households and enterprises, and public saving has been an important contributor to the region's exceptionally high savings rates.

Sure enough, Asia has had its crises too. In 1997, a financial crisis spread through East Asia and Southeast Asia, hitting the hardest economies where corporate borrowing had been excessive and mismatched in terms of both its time structure and currency denomination. After cleaning up affected financial and nonfinancial corporate sectors, governments tightened corporate laws and surveillance as well as monetary and fiscal policies. The region as a whole emerged from the crisis stronger and more disciplined, and with its banks, corporations, and foreign currency reserves less leveraged. The years to follow would also mark significant accomplishments in establishing or deepening domestic bond markets in Southeast Asia and elsewhere in the region.

Large current account surpluses and strong fiscal positions built since the late 1990s helped Asia weather the global crisis triggered by the 2008 United States subprime crisis, which spread from across the North Atlantic financial centers to Asia through the region's heavy involvement with the global trade and supply chain networks. Huge and largely unprecedented fiscal stimulus programs, together with monetary and other policies to stem the crisis' social and economic impacts, contributed to a rapid recovery from the economic slowdown, and the region quickly resumed a path of rapid growth that had set it apart from the rest of the world for the better part of the past four decades.

However, the global crisis did accelerate some major structural shifts in the region. Most notably, rebalancing in the People's Republic of China toward domestic consumption and a gradual move away from export and investment-led growth had become overdue. This cast waves across the regional supply chains, with effects magnified by a growing backlash against globalization. The region also witnessed a gradual shift toward higher South-South investment and capital flows, especially toward the lower-income countries and reshaping the traditional creditor composition. Meanwhile, advanced economies' ultra-easy monetary policy lowered global interest rates and flattened yield curves on reserve currencies to levels unseen before, triggering a massive flow of hot capital toward emerging markets - in Asia and elsewhere - in a desperate run for higher yields. 
These and other risk factors sent some warning lights flashing well before the coronavirus disease (COVID-19) pandemic caught the world by surprise in early 2020. Among Asia's lower-income countries, risk ratings from debt sustainability analyses had long been signaling rising concerns about possible distress. Major structural hurdles, extreme exposure to natural hazards, and typically weak debt management and governance were perpetuating and sharpening these countries' dependence on concessional loans and grants at a time when complex debt profiles were complicating the prospects for debt workouts and creditor coordination. Among the region's emerging markets, worrying signs had emerged in relation to ballooning corporate leverage in some, rising household debt and financial sector vulnerabilities in others, and to the risk of sudden stops and capital reversals in economies with a large exposure to unhedged foreign-owned positions or jittery domestic investors.

When the pandemic hit, Asia's economies ground to a halt, just like the rest of the world. Governments' fiscal response has been robust so far, especially in the larger emerging economies with sufficient fiscal space available. Financial support by the Asian Development Bank and the creditor community more broadly helped bridge the financing gap from heightened spending on health, social, and economic measures, especially in lower-income countries unable to stem by themselves the revenue compression from collapsing growth, lack of tourism receipts, dwindling remittances, and faltering commodity export prices. Thanks to strong international support, and to still favorable global liquidity conditions, the pandemic has not morphed into a full-blown emerging and lower-income market debt crisis. The outlook for debt sustainability in the region remains generally favorable, assuming that global vaccination programs will effectively break the pandemic's deadlock on the global economy and robust economic growth will return to Asia in 2022.

But there is no room for complacency, and policy makers had better prepare for the risks ahead. Amid much uncertainty, continued access to international capital markets and the avoidance of flow reversals and rollover constraints remain critical to sustainability of external debt, including private leverage where it looms large. Rising interest rates or less than accommodating conditions in support of countries already pressed hard for liquidity could spell trouble in several parts of the region. As if this was not enough, policy makers and their development partners are also facing new challenges from a sharp trend reversal in inequality and poverty brought about by the pandemic, on top of inexorable massive fiscal pressures arising from aging populations and the fulfillment of long-standing development prerogatives such as to close the large infrastructure gaps still present in the region.

Against this tall and urgent task, and without the aim of comprehensiveness, this book and the 17 chapters it collects put forward deep, rigorous, and policy-relevant analyses to help Asia prepare for what is to come.

Yasuyuki Sawada

Chief Economist and Director General (March 2017-August 2021) Economic Research and Regional Cooperation Department Asian Development Bank 